\title{
The Constitution of Malta: Reflections on New Mechanisms for Synchrony of Values in Different Levels of Governance
}

\author{
Peter G. Xuereb
}

\begin{abstract}
The report observes that the Maltese Constitution of 1964 has significantly been influenced by the British constitutional tradition. This includes references to Erskine May as the British parliamentary 'Bible', the Westminster model of cabinet and parliament, and the fact that the Constitutional Court has weaker powers (acts can be repealed by Parliament only). The concept of the rule of law is drawn from English constitutional textbooks, from Dicey to Wade. However, a key difference is that unlike in the UK system, Parliament in Malta is not supreme but is subject to the Constitution as suprema lex. The bill of rights in the Constitution is similar to the ECHR; some constitutional provisions are not enforceable (e.g. a clause on limitation of rights). EU and international law, broadly speaking, have not presented acute constitutional issues. Nevertheless, the report notes a gap in the protection of constitutional values at the EU level, and an even greater gap at the global level. A case is made that the national and the 'wider' level ought to operate in synchrony according to the same core fundamental values and principles. The report puts forward the suggestion to expand the so-called yellow card mechanism so that constitutional issues beyond proportionality and subsidiarity could be raised by national parliaments ex ante when a proposal for EU legislation is issued.
\end{abstract}

The author is and was at the time of writing Professor of European and Comparative Law, Head of the Department of European and Comparative Law in the Faculty of Law, and Chairman of the Institute for European Studies at the University of Malta; subsequently Judge at the Court of Justice of the European Union. e-mail: peter.g.xuereb@um.edu.mt.

All websites accessed 19 January 2015. Text submitted 21 January 2015.

P. G. Xuereb $(\bowtie)$

University of Malta, Msida, Malta

e-mail: peter.g.xuereb@um.edu.mt

(C) The Author(s) 2019

A. Albi and S. Bardutzky (eds.), National Constitutions in European

and Global Governance: Democracy, Rights, the Rule of Law,

https://doi.org/10.1007/978-94-6265-273-6_4 
Keywords The Constitution of Malta $\cdot$ EU amendments in the Constitution The Constitutional Court of Malta - Constitutional review • British constitutional influences - Fundamental rights and the rule of law - European Arrest Warrant and extraditions - Data Retention Directive and surveillance $\cdot$ Judicial dialogues Supremacy - Neutrality - AJD Tuna and the principles of legitimate expectations, proportionality and justice and the adversarial principle

\section{Constitutional Amendments Regarding EU Membership}

\subsection{Constitutional Culture}

1.1.1 The Maltese Constitution ${ }^{1}$ of 1964 , known as the Independence Constitution, was a post-Colonial constitution of the 1960s that spoke of the Queen of the United Kingdom as the Head of State of what effectively was a new, independent state within the British Commonwealth. It was amended in 1974 to constitute Malta as a Republic within the Commonwealth of Nations, by Act LVIII of 1974, and the first Maltese (non-executive) president was appointed. The Westminster model of cabinet government was selected, and Erskine $\mathrm{May}^{2}$ is still the parliamentary reference point, but otherwise the model of a written constitution, replete with a reasonably extensive and judicially enforceable bill of rights inspired by the European Convention on Human Rights of 1950 (hereinafter European Convention or ECHR), and with limitations on parliamentary sovereignty, was chosen. A status of 'active neutrality' was enshrined in the Constitution in 1987 by an amendment made by Act IV of 1987. Membership of the European Union required some further changes, but not so as to affect the essential fundamentals of the state or in such a manner as to render the changes irreversible. Leaving the EU would be just as easy in terms of parliamentary action as was joining. An Act of Parliament passed by majority and repealing the European Union Act 2003, the national Act of Parliament providing for membership of the Union by incorporating the EU acquis, would suffice. Still, no sovereignty clause appears in the Constitution, save as to the supremacy of the Constitution over any other law, with ultimate political sovereignty implicitly lying with the people. The author's preference de lege condenda would be for inclusion in the Constitution of an express declaration of the principle that sovereignty resides in the people.

It can be said that the Maltese Constitution is equally 'legal' and 'political'. Like other constitutions of the new Commonwealth, the new Constitution preferred to spell things out as a matter of strict law rather than leave matters to residual discretion. ${ }^{3}$ As an independence constitution in origin and a republican constitution

\footnotetext{
${ }^{1}$ http://justiceservices.gov.mt/DownloadDocument.aspx?app=lom\&itemid=8566.

2 The British Parliamentary 'Bible'.

${ }^{3}$ Cremona 1997, p. 77.
} 
in actuality, it provides the supreme law of the land, while doing so against a heavy political and legal backdrop of evolving membership of the regional (European) and international (global) communities.

1.1.2 The rationale of the Constitution consists both of establishing statehood and sovereignty and of limiting the exercise of public power. While the locus of the ultimate political power is left unstated, except that the people are clearly sovereign every five years in terms of the obligatory general elections, Malta is constituted as a sovereign state and a national polity, with democratic political institutions that are clearly but not expressly subject to the rule of law and an independent judiciary called upon to enforce the Constitution and laws made under it. The Constitution both (a) declares sovereignty in international law and organises the state and (b) limits the exercise of power internally by reference to constitutional rights and liberties and checks and balances, as well as international obligations. It is hard to say that any one of these dominates. But it is clear that Parliament is not supreme (unlike in the traditional UK sense), for Parliament is subject to the Constitution as suprema lex. Professor J. J. Cremona cites Professor Sir Kenneth Wheare as stating that the supremacy of a constitution over the institutions which it creates derives from its very nature; it not only regulates the institutions but also 'governs the government'. It is from this combination of factors that the effective application of the principle of the rule of law emerges. In Professor Cremona's view, Art. 6 of the Constitution - the supremacy clause - merely (and redundantly, as well as dangerously - because it subjects it to possible amendment) restates this otherwise implicit principle. ${ }^{4}$

The observance of international law is key, as is the observance of human rights. Of the two, it is perhaps the former that is the more highly evolved, with lessons still to be learned in the area of human rights and individual remedies. Having said that, there is also room for improvement on the operation in practice of separation of powers and due checks and balances, and it is currently a question as to how and to what extent the model of cabinet government as it has evolved needs change. ${ }^{5}$

\subsection{The Amendment of the Constitution in Relation to the European Union}

1.2.1 Although there was arguably no need to make provision in the Constitution for EU membership, it was thought prudent to do so. The result was the amendment of Art. 65(1) of the Constitution, which reads as follows:

\footnotetext{
4 Cremona 1997, p. 106.

5 The Today Public Policy Institute 2014 Part II paras. 26 et seq., and 72 et seq.
} 
65. (1) Subject to the provisions of this Constitution, Parliament may make laws for the peace, order and good government of Malta in conformity with full respect for human rights, generally accepted principles of international law and Malta's international and regional obligations in particular those assumed by the treaty of accession to the European Union signed in Athens on the 16th April, 2003.

Article 65 was given this current form by the European Union Act, Act V of $2003,{ }^{6}$ Art. 7. It is in virtue of this Act that Malta has acceded in due course to subsequent treaties, including the Lisbon Treaty in 2007.

It is clear that Art. 65(1) cannot operate as a permanent commitment to membership of the Union for the reason that Art. 65(1) can be amended by a majority of all the Members of the House under Art. 66(5) of the same Constitution. It was presumably thought, however, that the Constitution should contain some reference to the Union inasmuch as joining the Union was a highly controversial national political issue, not least for the reason that a considerable transfer to the Union institutions of, and limitation on, legislative power for the future was involved. However, ultimate sovereignty is clearly retained in the Constitution in the form of the maintenance of the alterability of this constitutional provision.

1.2.2 The Constitution was amended by majority in Parliament, ${ }^{7}$ following a non-binding referendum in favour of membership and a subsequent national election won on the basis of a mandate to take Malta into the Union. The Constitution was amended by Act No V of 2003, titled the European Union Act of 2003.

The relevant rules are in Art. 66, sub-arts. (5) and (7) (b) as follows:

(5) In so far as it alters any of the provisions of this Constitution other than those specified in sub-articles (2) and (3) of this article, a bill for an Act of Parliament under this article shall not be passed in the House of Representatives unless at the final voting thereon in that House it is supported by the votes of a majority of all the members of the House.

(7) In this article - (b) references to the alteration of any of the provisions of this Constitution or of the Malta Independence Act, 1964 include references to the amendment, modification or re-enactment, with or without amendment or modification, of that provision, the suspension or repeal of that provision and the making of a different provision in lieu of that provision.

The Lisbon Treaty was given effect in Malta via the application of Art. 2(2) of the European Union Act 2003, which empowers the Prime Minister to order that any new Treaty be 'treated as one with' the Treaty signed in Athens in April 2003. This was done by the Treaty of Lisbon Order (S.L. 460.20, Legal Notice 42 of 2008), which was promulgated on 1 February 2008.

\footnotetext{
${ }^{6}$ http://www.justiceservices.gov.mt/DownloadDocument.aspx ?app=lom\&itemid=8926\&l=1.

7 It may be noted in passing that the amendment of some specified provisions of the Constitution, notably the provision on the prorogation or dissolution of the House of Representatives, requires a referendum vote in favour. See Art. 66(3) of the Constitution.
} 
1.2.3 The amendments were made as a matter of course. Ever since the controversy on membership was decided in political terms by the general election of 2003, with the Labour Party changing its policy on EU membership as a result of its defeat at the polls in an election dominated by the membership issue, national consensus has prevailed on the issue of Malta's continuing membership, which was also demonstrated by the unanimity on the vote in Parliament for ratification of the Lisbon Treaty and the consequential amendment of Maltese law. The amendments were drafted by the Office of the Advocate General.

1.2.4 There have been no further EU-related amendment proposals.

\subsection{Conceptualising Sovereignty and the Limits to the Transfer of Powers}

1.3.1 As far as the relationship between Maltese law and EU law is concerned, this is covered by Art. 3 of the European Union Act of 2003, Chap. 460 of the Laws of Malta, which provides:

(1) From the First day of May 2004, the Treaty and existing and future acts adopted by the European Union shall be binding on Malta and shall be part of the domestic law thereof under the conditions laid down in the Treaty. (2) Any provision of any law which from the said date is incompatible with Malta's obligations under the Treaty or which derogates from any right given to any person by or under the Treaty shall to the extent that such law is incompatible with such obligations or to the extent that it derogates from such rights be without effect and unenforceable. ${ }^{8}$

In the first place, this provision encapsulates the transfer of legislative power to the Union effected by the signature of the Treaty(ies) and their ratification by Malta. My analysis is that this transfer occurred upon signature and then ratification by the passage and coming into effect of the European Union Act, in virtue of Art. 65 of the Constitution. Secondly, this provision encapsulates the 'supremacy' of Union law (this by effect of Art. 3(2) of the European Union Act).

1.3.2 There have been no statements on the transfer or delegation of sovereignty by the Maltese Constitutional Court itself. The author's view is that there has been, objectively speaking, a transfer pro tempore of legislative power (as long as Malta remains a Member State and the European Union Act remains in force) to the institutions of the Union in the fields of competence of the Union and subject to the Treaty procedures for the exercise of that competence, and that Maltese constitutional theory must be regarded as accommodating this. However, precisely how this would be articulated by the Constitutional Court is an open question in the absence of any indications from it on this matter.

${ }^{8}$ http://www.justiceservices.gov.mt/DownloadDocument.aspx?app=lom\&itemid=8926\&l=1 . 
1.3.3 The limits are to be found embedded in the wording of Art. 65 of the Constitution. They are not particularly strict. It is most unlikely that the Constitutional Court would second-guess the determination of Parliament, except where the effect of a parliamentary resolution would undermine the very fabric of the Maltese state and sovereignty itself. This is because ultimate and entire sovereignty continues to reside in the Maltese state as constituted by the Constitution; Malta is a state under international law, and Malta cannot cease to be such by virtue of any action taken by Parliament under Art. 65 as it stands. However, there is a major caveat, since in theory at least there is the legal possibility of amendment of every constitutional provision, although the applicable procedure can vary and would follow one of three different modes, but with one of them available for each provision of the Constitution. Even Art. 1, constitutive of the Republican State of Malta, and Art. 6 (supremacy of the Constitution) can (at least textually and theoretically) be amended by special majority in Parliament under Art. 66(2).

Thus, any major overhaul of the State of Malta would at the very least require a two-thirds majority vote in Parliament, in some cases with a referendum result in favour, but politically-speaking, surely full consensus bordering on unanimity among the citizens of Malta would be needed. It is not known whether the constitutional revision exercise currently under way will propose a greater direct role for the people. The dynamics of the constitutional development of the Union itself and Malta with it may well play a role in any debate on these lines.

1.3.4 The Constitutional Court has not had occasion to proclaim the supremacy of EU law over the national Constitution or vice versa, for example in particular in the context of an alleged conflict between a constitutional provision and Union law. Nor, arguably, could it do so in such stark terms. The constitutional accommodation of the supremacy of EU law rather appears to take the form of an Act of Parliament passed in virtue of the Constitution and to be applied in practice by loyal co-operation and 'co-operative interpretation/constitutionalism/dialogue', but with the Maltese legal and constitutional system retaining a hypothetical 'final say' for the Maltese Constitution/Constitutional Court regarding (a) the interpretation of the Constitution, and (b) the applicability or otherwise in a particular case of an EU rule.

This is because the Constitution, in Art. 6, expressly declares that the Constitution is the supreme law of the land by declaring that:

6. Subject to the provisions of sub-articles (7) and (9) of article 47 and of article 66 of this Constitution, if any other law is inconsistent with this Constitution, this Constitution shall prevail and the other law shall, to the extent of the inconsistency, be void [emphasis added].

There is, therefore, potential (perhaps only hypothetical) conflict with Art. 3(2) of the European Union Act, inasmuch as this latter provision appears to provide for the supremacy of Union law, not only in the sense of applicability in a particular case but by rendering any 'incompatible' Maltese law pro tanto ineffective and void of effect. The apparent conflict would be removed if the word 'law' in Art. 3(2) 
were read to exclude the Constitution, but the latter itself refers to itself in terms of being a law, ${ }^{9}$ and in any case the intention of the legislator in the European Union Act was clearly that of incorporating the acquis which, as is well known, predicates the 'supremacy' of Union law over conflicting national law 'however framed'.

If any EU law were applicable in Malta but inconsistent with the Constitution, then presumably that would pro tanto and in that case render the European Union Act (which mandates its application) inconsistent with the Constitution (requiring its non-application), making the Act itself also pro tanto and in that case void and of no effect. This is one reading and does not exclude any other analysis or interpretation being made by the courts. However, the Maltese courts will always first seek to reconcile the Constitution and any other law with EU law as a matter of interpretation before finding any 'conflict' between such laws.

The Maltese legal system generally follows the line that all Maltese law will be interpreted in line with Malta's international obligations, which include its obligations as referred to in the European Union Act 2003. The Maltese courts have unequivocally accepted the direct applicability of EU regulations and declared them to be applicable in preference to conflicting national law. ${ }^{10}$

\subsection{Democratic Control}

1.4.1 The Standing Committee on Foreign and European Affairs is the parliamentary body charged with checking draft Union legislative proposals for compliance with subsidiarity. In practice, Parliament is more or less dependent in this regard upon the Government for information and analysis as to the impact of proposed EU legislation on Malta generally, and the economy or industry, whether in general or in particular, lacking as it still does the resources to do this entirely independently in a satisfactory way. Key subsidiarity issues are sometimes missed. Parliament has at times sought to give itself effective autonomy in this regard, but with no lasting success as yet.

1.4.2 The first EU-related popular referendum was 'voluntary' and held by a Nationalist Party (conservative) Government in order to sound out the people on membership. The referendum was not mandated by the Constitution and was non-binding in legal terms. The majority Yes vote (for Union membership) result was discounted by the opposition party as being simply non-binding. Membership of the EU was then in fact decided in political terms by a general election, held within weeks of the referendum in March 2003, with the losing opposition party accepting the result of the general election as the people's definitive verdict on EU membership. No other referendums have been held since then on purely EU

\footnotetext{
9 Article 6 speaks of 'any other law' (author's italics).

10 See for example, Sansone v. Comptroller of Industrial Property, Court of Appeal, Application 15/20 of 2005, decided on 22 March 2006. See generally Sammut 2009.
} 
matters. Maltese law (including the Constitution) does not as a rule require the holding of a referendum for constitutional change, although it does require the use of referendum in the case of some constitutional amendments and also provides for abrogative referendums. Direct democracy is not a main feature of the Maltese constitutional scene, although Governments have occasionally employed a non-binding referendum. The current constitutional revision process, which commenced in 2014 on Government initiative ${ }^{11}$ but without a clearly defined starting point, is meant to consider the possible introduction of referendum as a tool of direct democracy. ${ }^{12}$

\subsection{The Reasons for, and the Role of, EU Amendments}

1.5.1 The amendment of Art. 65 of the Constitution was probably dictated by a perceived need to legitimise membership by reference to some form of transfer of power clause or constitutional competence. The opposition had been arguing that Art. 6 of the Constitution (the supremacy of the Constitution clause) precluded EU membership, and that this article would need to be deleted for Malta to be able to join; indeed the Government had received this very advice. The present author had argued that neither this nor the insertion of an 'EU law supremacy clause' was strictly needed nor indeed desirable, and that Member State practice as to constitutional provisions on the question of conflict of national law with EU law was widely divergent, including in the then current Member States; there has been a marked tolerance for an understated approach as long as it appeared clear that EU law would in practice be given application as and where required by EU law. However, the lack of a constitutional provision permitting and regulating the transfer of legislative power was, it seems, considered a lacuna, and the solution was the amendment of Art. 65 to provide expressly for this vis-à-vis the European Union. The Constitutional Court was not involved. It was a combination of the desire of Government to do, and appear to be doing, things constitutionally and transparently, to regulate matters rather than leaving them to later chance interpretation or attack, in combination with the relative ease of making the necessary amendment once it was realised that the Union acquis did not actually require the deletion of the supremacy clause (Art. 6), far less its substitution by an EU law supremacy clause. The general public was by now in relatively strong acceptance if not support of Union membership. Therefore, the constitutional culture, the quest to enhance the legitimacy of EU membership, the need to take the Constitution seriously and to reflect the shift of power to the supranational level, the support of

\footnotetext{
11 The present Government had promised a constitutional convention on a possible 'second republic' in its electoral manifesto of 2013.

12 Generally see, for a contribution by an independent think-thank, The Today Public Policy Institute 2014.
} 
the public, as well as the relative ease of the amendment procedure, all played their part in the introduction of a rather innocuous amendment to Art. 65 in the very same Act that rendered the EU acquis effective in Malta.

1.5.2 Perhaps the amendments were limited in scope due to the vehement opposition there had erstwhile been to membership of an increasingly 'federal' Union, often articulated in 'loss of sovereignty' and 'lack of voice' terms. The least controversial/inflammatory legal solutions were found. These were not the minimum required to allow the acquis to be put into effect. The European Union Act 2003, incorporating the Art. 65 constitutional amendment, replicated in large measure the wording of the United Kingdom's European Communities Act of 1972. Article 3 of the Maltese European Union Act was arguably strongly enough worded in terms of 'supremacy' as to at least raise a question of compatibility with the Constitution, but it seems that consensus about making membership work prevailed over hypothetical, and possibly sterile, debates.

As to 'waning constitutionalism', there has not been any real debate on this, but politicians from both sides have commented upon the democratic deficit within the Union. This is linked to a perception that it is hard for Malta and other small Member States to obtain solidarity-inspired attention from their fellow Member States in face of the general drive for deeper European integration, the strategies adopted by more powerful or influential Member States and the difficulty still found by the national parliament to properly monitor EU proposals, as well as other related issues. The Maltese feel close to their politicians, so that the syndrome of double remoteness is, in general, missing. Further, according to surveys, the Maltese are among the citizens who feel close to Brussels and other centres of policy/law-making in the EU. ${ }^{13}$ Their Members of the European Parliament are among the most readily accessible. However, the feeling is one of a domineering group at the centre. Domestically, it is accepted that the Constitution is in need of review also for domestic reasons to do with a heightened need for accountability of the national government, an outdated set of provisions on neutrality and new institutional demands, among other reasons. The review process is taking some time to gather momentum but interest in the Constitution (and its review) has not diminished. Indeed, it is thought of as an important and even vital safeguard in the supranational and international contexts, and the 'EU amendments' made were truly on the minimalist side. It is not thought likely that any policy shift will be made on that score.

1.5.3 The author's view is that the general opinion in Malta would be that it is vital for constitutionalism - in the sense of limited government - at national level to be intertwined with constitutionalism - in the same sense - at regional and global level. In other words, these other levels must themselves be 'appropriately' constitutionalised, especially if they are to be further empowered. The role of the

\footnotetext{
13 European Commission, Public Opinion in the EU, Standard Eurobarometer 82, Autumn 2014. http://ec.europa.eu/public_opinion/archives/eb/eb82/eb82_first_en.pdf.
} 
national constitution would not change, and the global constitutional picture must be reflected in the national constitution, but this also applies in reverse. The real challenge then is to devise the regional and global constitutional compact under the form of constitutionalism and most crucially to build appropriate mechanisms of voice and solidarity (in both the procedural and substantive senses) into this regional and global constitutionalism. At regional European level, the Lisbon Treaty (building on the Constitutional Treaty) quite clearly set out to do more of this, but a gap remains. We have a much larger gap at global level. At the same time, constitutional tolerance is said to be a key value. Power is increasingly exercised at supranational level because it is being transferred to this level or even simply taken at this level. It is up to states to balance the transfer of powers to this level with added constitutionalism and constitutional values operating at this level. In the author's view, changes to national constitutions would best be designed in a context which involved the constitutionalisation of the exercise of power at the 'higher' level according to a multilevel - or (as I prefer) on a 'wider' scale (if we use the language of the 'horizontal' constitutionalism model). Both levels or spheres should operate in synchrony according to the same core fundamental values and principles. New mechanisms and instruments need to be devised for this purpose.

We have recently witnessed the need for constitutional accommodation in most Member States to permit new Union powers or the unforeseen exercise of power at Union level. This is emerging as something of a trend. In my view - and this view was expressed at the time of the future of Europe debate at the turn of the century but resonates even more powerfully today - the final understanding and adoption of the principle of solidarity (enforcing the value claimed by the Treaty) is the key. With true and active solidarity even full integration can be achieved, but without it every step will prove tortuous and fraught with backtracking and avoidance. An active principle of procedural and substantive solidarity ${ }^{14}$ - not to be confused with a redistributive policy - would be based on a multi-level dialogic approach that applied - through the Institutions - the practice of input and output legitimacy based on taking different national interests into full account, weighing them against the common good at EU level, and then proceeding to balance the proportionate pursuit of the EU level common good by the safeguarding or accommodation of each national interest. This is a combined solidarity and common goods approach to the future parallel constitutional evolution of the Treaties and of the national constitutions. It is not only about respect for the essence of national constitutions. It goes beyond this, to respect for legitimate national interests. This practice of real solidarity requires a constitutional underpinning at both Union and national level. If put in place, it would allow for the pursuit of ambitious aims at EU level while securing maximum agreement for the required action at EU level - precisely through the solidary respect for legitimate individual national interests. Legislative and other decision-making procedures would be adapted to provide for this.

14 See Xuereb 2002. 
Mechanisms of review and challenge would ensure that an objection could be made to the use of power otherwise than in accordance with this principle of solidarity. For example, I would argue that the subsidiarity yellow card procedure should be extended to the exercise of the solidarity principle (and duty). Or a parallel structure could be created. If a certain number of Member States felt that a legislative proposal did not evince a reasonable degree of solidarity, the procedure would send the proposal back for further consideration at that early stage. In fact, other grounds of a constitutional nature might be added, so that the monitoring and review by national parliaments would be made to cover other constitutional issues, such as the proper observance of human rights (for details, see Sect. 2.12.3). Such mechanisms would ensure early consultation and dialogue, and ultimately pre-empt the possibility or even certainty in some cases of 'post-adoption challenges' to EU measures, not only before the Court of Justice but also before national supreme courts. In the latter case any challenge would have to have its basis in national law, meaning that a clash would have occurred between Union legislation and national (possibly constitutional) law. It would be far better to recognise principles at EU level and ensure their application or enforcement at this level (with full dialogue between levels) than to adopt legislation or other measures that give rise to chagrin at national level and legal challenges at that level that would have to be settled by reference to national law. It is far more likely that the necessary accommodations will be found through a process that ensures solidarity ex ante rather than one that relies on raw majoritarianism with the possibility of subsequent challenge on grounds that require of the Court something that a sensitive Commission and political process are far better able to deliver. I have written elsewhere that

[a]s recent events in the Union have shown, state sovereignty needs to be constantly re-evaluated. Otherwise national interest will be pursued not through cooperation, but through the power of the veto, and even when this obstructs the pursuit of the wider common good. This makes it a constitutional issue for all the Member States and the Union as a whole. ${ }^{15}$

\section{Constitutional Rights, the Rule of Law and EU Law}

\subsection{The Position of Constitutional Rights and the Rule of Law in the Constitution}

2.1.1 Since 1961, Malta's constitutional documents have featured a list of fundamental rights with corresponding action for enforcement. The Constitution of 1964 is the main document but the list of rights was enhanced by the European Convention Act of 1987, which extended the same right of action to the new rights

15 See Xuereb 2012, p. 169. 
derived from the European Convention on the Protection of Human Rights and Fundamental Freedoms of 1950 (ECHR). As to the general principles, they have tended to emerge almost as a matter of custom in the 'gurisprudenza' (judgments) of the courts, especially of the First Hall of the Civil Court in its constitutional jurisdiction, and of the Constitutional Court. General legal principles are not applied in a way that they could be considered as sources of fundamental rights protection. $^{16}$

\subsubsection{Article 32 of the Constitution provides as follows:}

Whereas every person in Malta is entitled to the fundamental rights and freedoms of the individual, that is to say, the right, whatever his race, place of origin, political opinions, colour, creed, sex, sexual orientation or gender identity, but subject to respect for the rights and freedoms of others and for the public interest, to each and all of the following, namely - (a) life, liberty, security of the person, the enjoyment of property and the protection of the law; (b) freedom of conscience, of expression and of peaceful assembly and association; and (c) respect for his private and family life, the subsequent provisions of this Chapter shall have effect for the purpose of affording protection to the aforesaid rights and freedoms, subject to such limitations of that protection as are contained in those provisions being limitations designed to ensure that the enjoyment of the said rights and freedoms by any individual does not prejudice the rights and freedoms of others or the public interest [emphasis added].

This preambular set of limitations is reflected in specific provisions legitimising derogation in the case of each right (except for protection from inhuman or degrading treatment), such as 'by a provision of law which is reasonably required in the interest of public safety, public order, public morality or decency, public health or the protection of the rights and freedoms of others'. Several provisions speak both of 'reasonably required' and 'reasonably justifiable in a democratic society'. The standard is substantially similar to that of the ECHR. ${ }^{17}$

2.1.3 While the rule of law underpins its entire edifice, there is no direct reference to this principle in the Constitution. ${ }^{18}$ Under threat at certain points in history, it has been strengthened from time to time. For example, as a reaction to the non-appointment of Constitutional Court judges between 1972 and 1974, the Constitution now provides an automatic mechanism for the constitution of the Court in default of specific nominations (Art. 95(5) of the Constitution). Other aspects include access to justice, the hierarchy of the courts and the system of appeals. Again, at one stage it seemed as if the First Hall of the Civil Court was subverting the hierarchical system by insisting that its 'original' jurisdiction gave it a power of review over the Constitutional Court, centring around the issue of how

16 Azzopardi 2012.

17 Cremona 1997, p. 82.

18 An initial discussion document was produced in September 2014 by 'The Today Public Policy Institute' (TPPI), with a view to launching a public debate on constitutional reform on these lines. The TPPI has recommended that this and other principles be considered for incorporation in the Constitution via a future Constitutional Convention amending the Constitution. The Today Public Policy Institute 2014, paras. 22-25. 
an alleged breach of fundamental rights by the Constitutional Court itself was to be remedied if not by a new action before the First Hall in its constitutional jurisdiction. ${ }^{19}$ In the course of such traumatic episodes, the language of the rule of law has tended to be heard.

The concept is drawn upon in legal education and training from English constitutional text-books and authors, from Dicey to Wade, and Lords Denning and Bingham, and is a point of reference in our constitutional judgments. Access to justice is a key principle. In the fundamental rights context it takes the form of the (relatively recent) right of action safeguarded by the Constitution and available for the protection and enforcement of the rights listed in Arts. 33 to 45, as well as the rights covered by the European Convention Act 1987. The novelty of this right of action was that it was made available also in the case of potential ('likely') breaches of a fundamental right. However, there is a proviso to the availability of this right of action. The proviso in Art. 46(2) reads: 'Provided that the Court may, if it considers it desirable so to do, decline to exercise its powers under this sub-article in any case where it is satisfied that adequate means of redress for the contravention alleged are or have been available to the person concerned under any other law.' The non liquet permitted here is unusual for the Maltese legal system. ${ }^{20}$ Ultimately, as $^{2}$ Professor J. J. Cremona, the main author of the 1964 Constitution, has written, it is allegiance to the rule of law that provides for the proper working of the Constitution. The clear implication is that it is not some document that of itself guarantees the rule of law but a vigilant people that will use the Constitution, whether regarding proper law-making, independence of the judiciary, hierarchy of the courts or human rights provisions to guarantee the rule of law in practice. ${ }^{21}$ Of course, the document must be so orientated. Access to justice, a fair trial, enforcement of civil rights by an impartial and independent tribunal, and other key elements of the impartial application of law and administration of justice are enshrined in the so-called right to the protection of the law in Art. 39 of the Constitution. Principles stemming from the rule of law, such as due process, fairness, fair hearing and audi alteram partem are recognised as fundamental rights as a result of Art. 6 ECHR, made part of Maltese 'supreme' law by the European Convention Act of $1987 .^{22}$

The Constitution provides that laws shall only come into effect when published, but that Parliament may make laws that are retroactive. Art. 72 provides:

(1) The power of Parliament to make laws shall be exercised by bills passed by the House of Representatives and assented to by the President. (2) When a bill is presented to the President for assent, he shall without delay signify that he assents. (3) A bill shall not become law unless it has been duly passed and assented to in accordance with this

19 See on this, Mifsud Bonnici 2004, paras. 15-28.

20 See further, Mifsud Bonnici 2004, Chapter VI.

21 Cremona 1997, p. 118.

22 Azzopardi 2012. 
Constitution. (4) When a law has been assented to by the President it shall without delay be published in the Gazette and shall not come into operation until it has been so published, but Parliament may postpone the coming into operation of any such law and may make laws with retrospective effect.

While Parliament may make laws with retroactive effect, Art. 39(8) of the Constitution entrenches the principle that a person cannot be convicted of a crime if the act or omission, when it took place, did not constitute such an offence.

\subsection{The Balancing of Fundamental Rights and Economic Freedoms in EU Law}

2.2.1 There have been no cases specifically on this matter. However, issues can arise where economic freedoms clash with classic rights as interpreted and applied in Malta in certain cases. For example, abortion, seen as an assault on 'life', remains a criminal offence under Maltese law. On this basis attempts to provide this 'service' (as described by the Court of Justice) in Malta or to procure or otherwise arrange for it to be obtained outside Malta have met with police or other action. There has been one difficult case in which a father attempted to stop his partner from proceeding abroad for an abortion. Another example involved the surgical separation of twins that were joined at birth where one of them (the more viable one) stood a chance of surviving if the operation were carried out, but with the certain knowledge that the other would die 'during' any operation to separate them and that both would certainly die without any surgical intervention. The matter was finally decided in an English court (where the twins had been taken) in favour of the operation (carried out in the UK), ${ }^{23}$ but the outcome would conceivably have been different in a Maltese court (and hospital), and any economic right or freedom of movement right in play might possibly have been relegated to second place by a Maltese court.

As far as social rights are concerned, Malta is a Republic 'founded on work and fundamental rights and freedoms' (Art. 1(1)) and 'committed to social progress among nations' (Art. 1(3)), and the Constitution seeks to protect social principles by declaration (non-justiciable principles) in Chap. III. This creates a very strong presumption in favour of these principles and a strong rule of interpretation that all legislation must be in conformity with them. Thus, the Maltese courts are called upon to ensure balance between economic aims and rights, and social aims and individual rights. Nevertheless, as has been strongly asserted by a group of NGOs in their recent replies and recommendations in response to a Government consultation exercise on the protection of human rights, second generation rights sadly

23 Dyer 2000. 
remain non-justiciable as such, and third generation rights are totally absent from the Constitution. ${ }^{24}$ Any future constitutional review must remedy this situation. ${ }^{25}$

\subsection{Constitutional Rights, the European Arrest Warrant and EU Criminal Law}

\subsubsection{The Presumption of Innocence}

2.3.1.1 The Constitution provides for the presumption of innocence in Art. 39(5) as follows:

Every person who is charged with a criminal offence shall be presumed to be innocent until he is proved or has pleaded guilty: Provided that nothing contained in or done under the authority of any law shall be held to be inconsistent with or in contravention of this sub-article to the extent that the law in question imposes upon any person charged as aforesaid the burden of proving particular facts.

This does not appear to have caused any difficulty for application of the European Arrest Warrant (EAW) regime. The fact that Art. 39(5) has not been amended means that there has not been any articulation of a 'compromise' if any was considered necessary as a result of the introduction of the EAW. ${ }^{26}$ It is arguable that Art. 34 of the Constitution, which protects the right to freedom from arbitrary arrest or detention, could have been amended in order to better allow textually for the operation of the EAW. Nevertheless, it does not seem to have caused any problems or raised any controversy in practice. According to the European Commission Report of 2011 on the first five years of the operation of the EAW, Malta has not had problems applying the EAW regime. ${ }^{27}$ The grounds on which execution of an EAW has been refused relate to (a) ne bis in idem, $^{28}$ and (b) prescription. $^{29}$

\footnotetext{
24 Aditus et al. 2014, para. 18.

25 See The Today Public Policy Institute 2014, paras. 22-25 and 64.

26 The EAW was introduced by the Extradition (Designated Foreign Countries) Order of 7th June, 2004 as amended, S.L. (Subsidiary Legislation) No. 276.05, under powers given by the Extradition Act 1982, Chapter 276 of the Laws of Malta. http://www.justiceservices.gov.mt/ DownloadDocument.aspx?app=lom\&itemid=9718\&l=1.

27 COM (2011) 175 final, Report from the Commission to the European Parliament and the Council on the Implementation since 2007 of the Council Framework Decision of 13 June 2002 on the European Arrest Warrant and the Surrender Procedures between Member States. See Sammut 2012, p. 460 at pp. 469-470, who states that 'there are no specific problems involving Malta as (sic.) the AFSJ in criminal matters'.

28 Article 39(9) of the Constitution and Art. 14 of S.L. 276.05.

${ }^{29}$ Filletti (undated).
} 
2.3.1.2 The courts will not simply rubberstamp a request for extradition, but will ensure that the evidence produced is satisfactory. ${ }^{30}$ There is no report of a request being reviewed on the ground of a claim of innocence by the person concerned. ${ }^{31}$

\subsubsection{Nullum crimen, nulla poena, sine lege}

2.3.2.1 These principles are set out in Art. 39(8) of the Constitution, which provides that:

No person shall be held to be guilty of a criminal offence on account of any act or omission that did not, at the time it took place, constitute such an offence, and no penalty shall be imposed for any criminal offence which is severer in degree or description than the maximum penalty which might have been imposed for that offence at the time when it was committed.

In my opinion, these principles are given the same level of protection today, and will be a ground for refusing extradition in principle. The dual criminality principle is regulated by Art. 10 of the Extradition Act and Art. 18 of the Extradition Order (S.L. 276.05), and there has not been any real criticism on this score.

\subsubsection{Fair Trial and In Absentia Judgments}

2.3.3.1 Under Art. 39 of the Constitution every person charged with a criminal offence is entitled to be present and to make his defence during related judicial proceedings. These rights are recognised by Art. 15 of the Extradition Act with regard to committal proceedings. The Maltese courts have not had occasion to review the standard of protection in this context.

\footnotetext{
30 See Art. 15, S.L. (Subsidiary Legislation) No. 276.05. For example see Police v. Andriy Petrovych Pashkov - Court of Criminal Appeal - 10/9/2009. Extradition Act (Chapter 276) Evidence collected in the requesting country: Documents purporting to set evidence heard on oath in the requesting country are admissible as evidence in extradition proceedings, although the witnesses were not heard in the course of judicial proceedings. The Act does not require that the witnesses must have been heard by a judicial authority. Although witnesses are heard according to the applicable procedure in the requesting country, the evidence has to be confirmed on oath or by affirmation or declaration, and must be duly authenticated according to law. In this case the documents filed by the prosecution did not show or disclose that the declarations made by the various persons heard by the authorities in the requesting country had been confirmed on oath or by declaration or affirmation. The Court of Appeal held that in the absence of such oath, declaration or affirmation, the documents were not admissible as evidence for the purposes of the Extradition Act.

31 See Cremona 1997, p. 118 and Dyer 2000.
} 


\subsubsection{Fair Trial - Practical Challenges}

2.3.4.1 All persons are entitled to legal assistance, legal aid and translation services. ${ }^{32}$ There is no particular NGO at the present time providing funding or assistance. I would support the creation of such a system as is proposed as an important counterweight to the disadvantages faced by persons facing criminal proceedings abroad, some of whom may well be innocent and in need of support and an informed liaison with the national authorities.

2.3.4.2 Based on the CEPS report mentioned in the Questionnaire regarding extraditions between 2005 and 2011, an attempt was made to identify cases through the study of media sources to ascertain the outcome of extraditions by reference to guilt or innocence as subsequently determined, with no result.

\subsubsection{Effective Judicial Protection: Mutual Recognition in EU Criminal Law and Abolition of the Exequatur in Civil and Commercial Matters}

2.3.5.1 There has been no constitutional case lodged on the lines of the Estonian case or similar. Nor has there been real debate as to the compatibility of mutual recognition and the rule of law, although misgivings have been expressed in the criminal field to the effect that the automatic application of mutual recognition could lead to a possible breach of fundamental rights by individuals falling into the gap between two or more legal systems. ${ }^{33}$

2.3.5.2 There has been no real debate on the suitability of the transposition of mutual recognition from internal market to criminal law. The author would agree with the view expressed by an academic colleague to the effect that '[c]riminal law must be based upon legal certainty and must be a condition (sic) of public trust. It must be based on the rule of law and for these reasons may not be equated with the economical (sic) field' ${ }^{34}$ Indeed, a balance needs to be struck around the concept of legal certainty according to real need, which raises the issue of proportionality.

2.3.5.3 Sammut has written that:

[A] further pivotal difference concerns the mode and effect of recognition. Mutual recognition in the internal market involves the recognition of regulatory controls and standards and is geared towards the national legislator and administrators. In the criminal field it involves the recognition and enforcement of court decisions by judges in order to primarily

32 Article 11(1A) of the Extradition (Designated Foreign Countries) Order, S.L. 276.05.

33 See for example, Sammut 2012, p. 470.

34 Ibid. 
facilitate the free movement of enforcement rulings. While the principle of borderless Europe applies in both cases, one has to be more careful in the criminal field. So fundamental rights are an issue but there is more than that. ${ }^{35}$

2.3.5.4 There have been no such calls in the sense of public statements on the desirability of the introduction of a proportionality test or for the (re-)introduction of some measure of judicial review. However, the concern expressed in some Member States is perfectly understandable on such points as the provision or otherwise of sufficient evidence of a case to answer, or whether an offence is sufficiently serious, or whether there is a sufficient link between the offence and the country to which the individual is to be extradited. In the author's view, there would need to be a fair balance in the standard of review set and possibly a maximum harmonisation approach taken. The German Government's call for a possible 'revision' of the rule of law in the EAW case is of interest, in my view, for the reason that it might lead, if not to a review of 'the concept of the rule of law', then at least to a restatement of an acceptable form of the common constitutional tradition of essential procedural safeguards in an extradition context, to be observed by all Member States. Equally, it is possible that best practice can indicate, with benefit to all interests involved, the re-instatement along standard lines of judicial review in civil and commercial matters.

\subsubsection{Constitutional Rights Regarding Other Aspects of EU Criminal Law}

A tangential aspect that has arisen and that straddles the 'national' and 'European' occurs in the i-gaming field, and may occur in other areas in the future. Some Member States are seeking to have their criminal law provisions, allied to a national requirement for the licensing of certain economic activity (for example, the provision of betting services), acquire automatic recognition and enforcement in other Member States and by EU law itself. This is even without formal harmonisation of criminal law at EU level, and sometimes via such methods as the promotion of Council of Europe Conventions on administrative, police and judicial co-operation. ${ }^{36}$ This prospectively raises acute issues not only for human rights or fundamental freedoms, but fundamentally for the interplay between constitutionally and Treaty-granted and protected economic rights on the one hand, and the limits of national sovereignty in criminal law on the other hand.

35 Ibid.

36 Mizzi, D. (2014, July 11). Malta seeks European Court ruling over sport betting convention. Malta Today. http://www.maltatoday.com.mt/news/national/41098/malta_seeks_european_court_ ruling_over_sport_betting_convention\#.VLZAZnt4FIY. 


\subsection{The EU Data Retention Directive}

2.4.1 Directive $2006 / 24^{37}$ was implemented by Legal Notice No. 198 of 2008 , which amended Subsidiary Legislation (hereinafter S.L.) $440.01^{38}$ - the Processing of Personal Data (Electronic Communications Sector) Regulations of 2003. In connection with these same Regulations, the Court of Appeal has held that any limitation on a human right (in this case the right to privacy) as protected by the Constitution, the European Convention Act of 1987 and the ECHR is to be interpreted restrictively and applied in strict accordance with the law. ${ }^{39}$ Apart from the disproportionate burden on the service provider if a police or security services request made under an exception is too widely drawn (as was found in this case), the human rights aspect was vital. The request in the particular case was such as to cover a wide area and potentially a very large group of persons, almost all of whom would be totally unconnected with any alleged offence (arson attacks). The Court noted the dangers of the wholesale placing of large groups of persons under suspicion, and the disclosure of data related to them without their knowledge, referring even to the road to totalitarianism and shades of a police state. ${ }^{40}$ Nor was such a strategy the only reasonable option for the police. The judgment therefore applies a form of reasonableness or proportionality to the facts. The case was decided before the implementation of the EU Directive, but is of interest in that it decided issues similar to the ones that featured in the annulment of the Directive.

Apart from being evidence of the application by the Maltese courts of a proportionality principle as a general principle of Maltese law and EU law when interpreting and applying Maltese law implementing EU law, the case also shows that the Maltese courts would be likely to regard a blanket rule on retention as a violation of the constitutional rights to privacy and integrity of the home and property under Art. 38 of the Constitution, and to freedom of expression, including the right to receive information and ideas, to communicate ideas and information without interference, as well as to freedom from interference with correspondence

\footnotetext{
37 Directive 2006/24/EC of the European Parliament and of the Council of 15 March 2006 on the retention of data generated or processed in connection with the provision of publicly available electronic communications services or of public communications networks and amending Directive 2002/58/EC, [2006] OJ L 105/54.

38 http://www.idpc.gov.mt/dbfile.aspx\%5CSL440_01.pdf.

39 Mobisle Communications Ltd. v. Kummissarju Ghall-Protezzjoni Tad-Data, Court of Appeal (Inferior Jurisdiction), Ref. No. 15/2006 decided on 3 October 2007.

40 In the Court's words: 'Mhux lanqas tollerat illi l-utenti kollha, indiskriminatament, jitqeghdu taht suspett biex a xelta taghha, il-Pulizija tkun tista' tgharbilhom bil-process ta' eliminazzjoni. Jekk dan jithalla jsir ikun qed javvicina l-qaghda ghal dak ta' stat polizjesk jew totalitarju li man-nozzjoni ta' socjeta 'demokratika u libera, kif nafuha, ma ghandu xejn x' jaqsam.' (at p. 28 of the relevant judgment). Translation by the author: 'Nor is it allowable for all users, indiscriminately, to be placed under suspicion with the Police then exercising discretion as to whom among them to eliminate from the investigation. That would be to approach the modus operandi of a police or totalitarian state, and one that is far removed from what is acceptable in a free and democratic society as we know it.'
} 
under Art. 41 of the Constitution. Police and security service powers are hedged around with strict controls and the need for high-level authorisation, and then apply only in the case of serious crimes or threats to public security. Data cannot be held for longer than is necessary, nor used for any purposes outside those stipulated by law, and communication and transfer are strictly controlled.

There have been no specific cases on the law implementing Directive 2006/24 as such, but the above is indicative. The Maltese courts would apply general principles to ensure a balance between powers and rights, as demonstrated by the Mobisle Communications Ltd. case above. The relevant provisions of the Constitution, however, do not reflect the digital age nor the essence of the core right to privacy of information in such an age. They are sorely in need of revision since as they stand, it is arguable that they themselves do not protect core rights as recognised by other applicable human rights documents, including the ECHR and the EU Charter of Fundamental Rights (Charter). A person is therefore more likely to turn to these latter documents, and the European Convention Act 1987 (Art. 32), when appropriate, in order to rely on a right to privacy that will then be circumscribed by the relevant EU-led legislation as well as by 'what can be shown to be reasonably justifiable in a democratic society' according to the terms of the Constitution. ${ }^{41}$ Article 32 of the Constitution states that 'every person in Malta is entitled to the fundamental rights and freedoms of the individual, that is to say, the right, ... but subject to respect for the rights and freedoms of others and for the public interest, to ... respect for his private and family life'. However, Art. 32 is not legally enforceable. $^{42}$ It is only possible to sue in the Maltese courts on grounds of 'private and family life' under Art. 8 of the European Convention Act 1987 (ECA 1987) and not under Art. 32 of the Constitution itself. Unusually for an ordinary piece of legislation, the ECA 1987 is enforceable through the competent courts. ${ }^{43}$ It can, however, be repealed via a simple majority vote in Parliament. Thus, the protection afforded by the ECA 1987 is not considered to be on par with the provisions in Chap. IV (Arts. 33-45) of the Constitution which are entrenched ${ }^{44}$ and require a two-thirds majority in Parliament to be amended.

Maltese law, as amended by the implementing law, has not been amended since the annulment of the Directive in April 2014. There is no official indication as to what action will be taken if any; however an inter-ministerial committee has been set up with a view to evaluating the situation and recommending an appropriate response.

\footnotetext{
41 The principal 'let-through' phrase found in both Arts. 38 and 41 of the Constitution.

42 See Art. 46. Article 32 is the only Article in Chapter IV of the Constitution entitled 'Fundamental Rights and Freedoms of the Individual' which is not enforceable before a court of law.

43 Generally, see Conference of European Constitutional Courts, XIIth Congress.

44 By virtue of Art. 66 of the Constitution.
} 


\subsection{Unpublished or Secret Legislation}

2.5.1 There has been no constitutional case on this. Certainly, it has been seen that there can be a strong political backlash if Parliament feels that it is not being kept sufficiently informed of administrative action. As things stand, Art. 72 of the Constitution requires all laws, of whatever nature, to be published in order to have effect. Therefore the concept of 'secret legislation' is a contradiction in terms. It is in this light that I would expect the Maltese Constitutional Court to react negatively to any call to apply the Heinrich judgment, as going a step too far.

\subsection{Rights and General Principles of Law in the Context of Market Regulation: Property Rights, Legal Certainty, Non-retroactivity and Proportionality}

2.6.1 Although Malta had similar problems as other Member States regarding sugar stocks upon EU membership, ${ }^{45}$ the stocks were lower than in the Central and Eastern European states (leading to a 1 million EUR fine in the case of Malta), and the Maltese courts have not been called upon to consider the issue or the general principles of law mooted here.

\subsection{The ESM Treaty, Austerity Programmes and the Democratic, Rule-of-Law-Based State}

2.7.1 The constitutionality of the European Stability Mechanism (ESM) was not overtly the primary issue for the Maltese Parliament. However, constitutional questions were especially at the root of interventions in Parliament made by former Prime Minister Alfred Sant. ${ }^{46}$ These included accountability to Parliament for use made of the European Financial Stability Facility, with the ratification treaty including a new clause that Malta's representatives on the ESM Boards of Governors and Directors were to report annually to the House Public Accounts Committee. Otherwise, the Government of the day argued that ratifying the ESM

\footnotetext{
45 Grech, H. and Camilleri, I. (2005, April 10). Malta Risks Paying Millions in EU Fine over Sugar Hoarding. Sunday Times of Malta. http://www.timesofmalta.com/articles/view/20050410/ local/malta-risks-paying-millions-in-eu-fine-over-sugar-hoarding.93850. See also: Camilleri, I. (2006, November 14). EU Fines Malta Nearly 1 Million Euros. Times of Malta. http://www. timesofmalta.com/articles/view/20061114/local/eu-fines-malta-nearly-euro- $1 \mathrm{~m} .35396$.

46 (2012, July 7). EU Financial Treaty Ratified. The Times of Malta. See also: Dalli, M. (2012, June 19). Malta supports ESM bailout for Spain. Malta Today. http://www.maltatoday.com.mt/ news/national/18986/malta-supports-esm-bailout-for-spain-20120619\#.VBA9uGN7SQc.
} 
was in the national interest as it offered a better financial alternative, with a surer cap on Malta's exposure (of some 160 million EUR) ${ }^{47}$ than the alternatives employed or which might be employed. The financial calculations appeared to dominate the parliamentary debate, but with underlying considerations of viability and control playing their part. There was no debate about the irreversibility or unconditionality of the commitment, as the issue was treated mainly as an issue of manageability.

2.7.2 General discussion about the constitutionality of other proposed measures has taken place internally in the financial institutions, the financial press and some conferences. $^{48}$ Amending the Constitution to allow for the Fiscal Compact's 'golden rule' required some debate, ${ }^{49}$ but in the end the consensus not to act by amendment of the Constitution prevailed. ${ }^{50}$

2.7.3 Malta has not been subject to a bailout/austerity programme. The author's view is that many in Malta would share much of the reasoning of the Constitutional Court of Portugal. It is worth recalling that the social progress of all nations is a fundamental principle and policy objective of the Constitution of Malta. ${ }^{51}$

\subsection{Judicial Review of EU Measures: Access to Justice and the Standard of Review}

2.8.1 With regard to indirect judicial review via preliminary references, the answer is that there has been one case where a question was raised as to the validity of Regulation 530/2008 and of Art. 7(2) of Regulation 2371/2002. The Court of Justice found Regulation 530/2008 to be partially invalid. ${ }^{52}$

2.8.2 The author shares the view that the Court of Justice of the European Union (CJEU) has demonstrated a propensity in the past to apply a liberal standard of review to EU measures. The national standard on the other hand requires a searching enquiry into the matter on the basis of general principles of law. Certainly, any review of an allegation of a breach of fundamental rights will apply a

47 For the Budget for 2015, the totals of Government revenue and expenditure are projected at around 3.5 billion euros and 3.7 billion EUR, respectively. See for example, http://www.act.com. $\mathrm{mt} /$ articles-publications/Budget-Measures-Implementation-2015.php.

48 See for example, Central Bank of Malta 2013.

49 Camilleri, I. (2012, March 3). No Decision yet on Constitutional Change. Times of Malta. http://www.timesofmalta.com/articles/view/20120303/local/No-decision-yet-on-the-constitutionalchange.409377.

50 For a full run-down of the Fiscal Compact ratification and related arguments in Malta, see European University Institute 2013.

51 Article 1(3), Constitution of Malta.

52 Case C-221/09 AJD Tuna [2011] ECLI:EU:C:2011:153. 
strict standard of compliance, and it may be that the latest Kadi judgment, ${ }^{53}$ among some others, will bring the CJEU closer to the national 'norm'. Importantly, it seems to indicate the possible emergence of a 'new constitutionalism' in the EU legal order, with human rights occupying a (more) central place in EU legal order discourse. At the same time, as has been noted by some, this seems to imply a (welcome) shift in focus from the market integration imperative to a broader constitutional, political and social underpinning for the rule of law in the EU legal order.

2.8.3 The Constitutional Court has exercised the power under Art. 6 of the Constitution to uphold the supremacy of the Constitution, including its human rights provisions, relatively vigorously. ${ }^{54}$ Yet it has been criticised for its stance that even where the European Court of Human Rights has ruled against the government in regard to the application of a law found to be in breach of human rights, the Constitutional Court considers itself unable to affect the (legislative) position for the future by declaring the legislative act in question 'null', which would apparently be seen as 'abrogating' the Act and as something that only Parliament is empowered to do. ${ }^{55}$ Of course, the Constitutional Court will declare anti-constitutional laws and acts to be 'to the extent of the inconsistency, void', in accordance with Art. 6 of the Constitution. ${ }^{56}$ All apparently turns on a claimed distinction between the meaning and effect of the terms 'null' (not used in the Constitutional provision) and 'void' (the term actually used). It is considered by the Constitutional Court to be a matter for Parliament to repeal the offending legislation. This could well be a vestige of the British constitutional influence, and may on this score provide a unique source of contrast with the position generally held in continental constitutional law.

2.8.4 There is no Constitutional Court ruling on the review of measures that implement EU legislation. The view of the author is that the Maltese Court would review the Maltese legislation/measures first and foremost under the Constitution, while interpreting the relevant EU legislation sought to be implemented according to EU norms, including the general principle of protection of human rights and the Charter of Fundamental Rights, but would carry out the review primarily in the

\footnotetext{
53 Joined cases C-584/10 P, C-593/10 P and C-595/10 P Commission and Others v. Kadi [2013] ECLI:EU:C:2013:518.

54 See generally, Mifsud Bonnici 2004. See also Zammit 2008.

55 See the controversy between Dr. Giovanni Bonello, former judge at the European Court of Human Rights, and Chief Justice Dr. Silvio Camilleri, with excerpts available at: Chief Justice Clarifies Position, The Judiciary 2013. http://www.judiciarymalta.gov.mt/newsdetails?id=86 and http://www.judiciarymalta.gov.mt/home?l=1. See also the comment by former Chief Justice and Judge at the European Court of Human Rights, Dr. Giuseppe Mifsud Bonnici in Bencini, A. (2013, May 26) Constitutional supremacy is self-evident. Times of Malta. http://www. timesofmalta.com/articles/view/20130526/opinion/Constitutional-supremacy-is-self-evident. 471246. See also The Today Public Policy Institute 2014, para. 79, where The Today Public Policy Institute observes that the Executive and the Legislature have 'in effect usurped' the power of the Constitutional Court to determine the validity or otherwise of laws under the Constitution.

56 See Degaetano 2008.
} 
context of the Constitution and of the European Convention Act of 1987. In my opinion, it would be theoretically (and very hypothetically) open to an applicant to argue that the Court should apply a higher standard than was being argued was the EU standard of protection, but he would need to do so by reference to a clear opposing prescription in the Constitution.

2.8.5 It is not suggested that the standard of review in Europe is considered to be necessarily lower than it is in Malta. The Maltese courts will, in practice, review measures implementing EU law for alleged breach of human rights. Also, I opine that the Maltese courts are likely to presume equivalence of protection, but will apply any higher standard as mandated by EU law and the Constitution itself. It is unclear what the courts would do if a lower standard of protection were indicated by EU law. This is hypothetical, as the European Convention provides a minimum standard in both spheres, and it has not been the subject of a statement by the Constitutional Court. Arguably, however, the Court would be obliged under the Constitution to apply the higher national standard according to the Constitution and the European Convention Act of 1987, and certainly up to the minimum standard of the ECHR. ${ }^{57}$

2.8.6 The broad issue of differential treatment has not been raised. In the author's view, it is highly unlikely that different standards would be applied in the absence of objective justification in a democratic society (if such were possible). The domestic protection would operate as the minimum standard at all events, as the human rights provisions apply to all persons present in Malta.

\subsection{Other Constitutional Rights and Principles}

2.9.1 There has indeed been an increase in, and possibly also a shift to, the use of ministerial power, through subsidiary legislation, for the implementation of EU directives. ${ }^{58}$ The result is one of less transparency, as well as less awareness, for all involved in the legislative process and afterwards. It may also be that in some areas the resulting complex of legislation in a particular area lacks cohesiveness or even coherence. To this may be allied the issue of 'copy/pasting' directives into national law. Again there are implications here for the democratic process, and ultimately the perception of EU legitimacy.

Another issue may be the apparent willingness of the CJEU to defer the application of the principle of proportionality to national laws which come up for

\footnotetext{
57 See further Azzopardi 2012.

58 There are no specific criteria in Maltese constitutional law for what has to be enacted as parliamentary statutes, except for the incorporation of certain treaties where an Act of Parliament is required.
} 
scrutiny as possibly infringing this principle of EU law, as well as fundamental Treaty law, to the national courts. The gaming sector is an example. The argument runs that if the rule of law means the uniform application in practice of fundamental treaty rights in all Member States, then to leave the ultimate determination of the proportionality of national measures which allegedly unjustifiably restrict the exercise of those rights to the national courts could militate seriously against the proper and uniform application of EU law, to the detriment of individuals seeking to exercise their rights under EU law.

\subsection{Common Constitutional Traditions}

2.10.1 Certainly, the rights and principles mentioned in the questionnaire, such as nulla poena sine lege and the right to judicial protection, could be among the candidates for principles that form part of the 'common constitutional traditions'. It might also secure broader agreement for permitting a move away from Art. 53 of the Charter if a new Convention were held in order to debate values in Europe, with a view to identifying common values (whether traditional or not), possibly on the basis of a report to be prepared by a team of experts. However, it is not clear that moving away from Art. 53 would be a good thing. Professor J. H. H. Weiler has famously $\operatorname{argued}^{59}$ for the retention of national legal systems as autonomous national laboratories of human rights, involving a bottom-up approach to the evolution of human rights. It is also for the Fundamental Rights Agency to monitor developments in the Member States with a view to identifying such commonalities.

2.10.2 The suggestion that courts making a reference might give more information to the Court of Justice as to the issues of national law - including constitutional law and the values that are thereby upheld - probably already exists as part of the exhortation for loyal co-operation between courts envisaged in the preliminary ruling procedure, at least in theory. This could be built upon if the national courts could be permitted to not 'settle' difficult questions of national law before making the reference (as the CJEU has requested in the past) but to submit the issue in the round, while of course limiting the formal questions to questions of EU law. Consensus issues such as the rule of law and so on - especially the principles underlying the rights - could with benefit from the subject of another democratic Convention (say on the Application in Practice of the Charter and the European Convention), an exercise which may or may not lead to treaty revision, but should lead to consensus or better mutual understanding.

59 Weiler 1999. 


\subsection{Article 53 of the EU Charter and the Issue of Stricter Constitutional Standards}

2.11.1 This is a difficult question for the EU, going forward. On one view, Art. 53 was part of the 'deal' in accepting the Charter as a legally-binding and enforceable document. It is part of the constitutional compact, based on a particular analysis of Member State systems and concepts of Union and citizenship (national and Union). Altering it would be seen as a fundamental Treaty change. The balance (resolution of conflict) between rights in a society, as long as a minimum standard is observed for each right, is a matter of national values and culture. It may also be related in some cases to 'national identity', arguably as protected by the national constitution. A full case (straddling law, society, culture, family, international relations, politics and so on) would need to be made for abandoning the national dimension of human rights (societal) development, which on the whole has tended towards a heightening of protection of rights, in favour of what can otherwise lead to a Europe-wide - indeed Union-led - search for, and commitment to, the lowest common denominator also in a cultural and values sense. One might also ask what role would be left for the national legislator and the national judge. There has been little discussion of these issues in Malta. In general, most are content that the standard of the ECHR, allied to the Charter, would likely apply. ${ }^{60}$ However, in the parliamentary debates leading up to the adoption of Act XIV of 1987 (the European Convention Act), it was emphasised that the European Convention standard would apply where the Convention gave greater protection, and that the principle should always be that the human rights provisions with the more extensive 'definition' should prevail. Also, it is realised that the EU legal order may take protection beyond the European Convention standard, and that this could lead to another layer of conflict as to the 'right' balance of rights. In short, clearer thinking is needed on the relationship between rights and values.

\subsection{Democratic Debate on Constitutional Rights and Values}

2.12.1 There was no public debate in Malta on constitutional rights at the time of implementation of the European Arrest Warrant Framework Decision ${ }^{61}$ or adoption of the EU Data Retention Directive.

2.12.2 There have not been any occasions from which conclusions can be drawn in this regard, as there has never been constitutional controversy over the

60 See Cremona 1997, p. 84.

61 Council Framework Decision of 13 June 2002 on the European arrest warrant and the surrender procedures between Member States (2002/584/JHA), [2002] OJ L 190/1. 
implementation of any EU law. In my opinion, the same scenario as occurred in Sweden and Germany could arise in Malta, but it is more likely that the issue would be flagged at an early stage and a solution of some kind would be found before the stage of implementation, especially on the issue of full debate.

2.12.3 I would prefer the emphasis to be on a system whereby such issues were flagged in advance of adoption, indeed ex ante at the time of the proposal of EU legislation, possibly on the model of the subsidiarity control, with the possibility of an ex post challenge before the Court of Justice if an allegation of breach of general principles or a challenge on other valid grounds could be made. However, as to the grounds for challenge, it is a question for discussion and study whether any challenge would be adequately governed by Art. 263 TFEU, including by reference to the principles set out in Art. 4(2) TEU and Arts. 52 and 53 of the Charter. The matter could perhaps be raised by a number of constitutional courts and/ or parliaments.

Therefore, in other words, I think that 'EU un/constitutionality' under the Treaties (I believe we can use this language since Lisbon at least) lends itself to an ex ante control as stated above. Indeed I would go further. In my view the ex ante control mechanism applied in the case of subsidiarity should be extended to all 'constitutional' issues, therefore including the principle of proportionality and, generally, all general principles of Union law (many of which, after all, are 'derived' from the common constitutional traditions of the Member States). This would allow proposals which are perceived to be problematic also from the national constitutional perspective to be flagged at an early stage, and would pre-empt both ex post challenges and outright 'rebellions' via national court proceedings that would otherwise result purely from the failure to address the EU-level constitutional arguments in their proper political forum at the earliest possible stage. The wider applicability of the yellow card procedure would allow for - indeed secure - proper and timely (early) consideration by the Commission of all constitutional implications and minimise the risk of any failure to consider and 'accommodate' (as and if necessary) national concerns about the proposed exercise of Union power as judged against the overriding norms of EU law. It would give national parliaments a mechanism for raising issues of national constitutional concern about the proper exercise of Union power according to EU norms at that early stage. It would be an exercise in solidarity and fit perfectly with the multi-level constitutional approach. It would then become far more likely that any domestic control would be focused on the domestic constitutionality or otherwise on the domestic implementing measure, treated as a separate issue from the EU constitutionality of the EU measure under the Treaty. Otherwise, of course, there could be ex post control before the Court of Justice, with the possible finding that an EU norm contradicts EU constitutional principles. But the rather damaging scenario of the Court of Justice having to annul an adopted measure because (or at least so it would damagingly appear from the perspective of synchrony between the EU constitutional safeguards and Member States' constitutions), of a national Constitutional Court objection would be much 
diminished. Moreover, fuller and more open democratic constitutional debate would be the result, with all the benefits of real multi-level constitutional dialogue.

\subsection{The Protection of Constitutional Rights in EU Law}

2.13.1 I have some concern about the apparent reluctance/incapacity of the Court of Justice to engage (possibly due to the absence of fuller Treaty powers) in an in-depth review of EU law and of national implementing law by fully applying the constitutional principles applicable, including the principle of subsidiarity, the principle of proportionality (including to national measures adopted to implement EU law) and settling human rights 'values issues', from an EU legal order perspective, thus omitting to give, in many cases where such clarity is warranted, a clear indication to the Member States that EU law is considered valid and applicable/inapplicable in certain ways. In exercising this jurisdiction, the Court of Justice would be guided by the (possibly revised) principles referred to in Sect. 2.12.3 above.

2.13.2 Exceptions have on the whole been made due to necessity and as proportionate, as in the case overall of the European Arrest Warrant. Nevertheless, the system may be permitting a lowering of standards in the European context, and permitting Member States to deny certain Treaty rights without fullest accountability. In my view, the ex ante and ex post controls in place against possible excesses can be improved, even from an 'efficiency in integration' perspective, for doubts and differences in Member States need to be ironed out before the stage of implementation if EU law is to be applied uniformly throughout the Union at the point when this is supposed to happen. At that stage it should be clear that the EU measure is legitimate, both because it is consonant with EU constitutionality and fully respectful of essential national constitutionality. Any shortcomings have probably been due to inadequate awareness, itself possibly due to the Union decision-making structures not being fully geared to the constitutional dialogue needed between the Union institutions and the Member States, and also due to some deficiency in the rules to be applied in such debate, i.e. the constitutional metarules - such as the reach of the principles of subsidiarity and proportionality (including the ability to raise a reasoned objection on the basis of the latter principle as part of the ex ante monitoring of EU proposals in national parliaments).

In my view, as long as the system ensures that subsidiarity and proportionality are applied at all levels, and access to a court in order to test their application is guaranteed, then the Court of Justice must be permitted to review Union acts and also national implementing acts for conformity with such acts. An EU Constitutional Court, as has been advocated by some over the years, might be the best candidate for such a role. At this point it then becomes important for the European Convention regime to operate with effectiveness upon the EU legal order, including upon the judgments of the Court of Justice, without unquestioned and 
irrebuttable presumptions as to equivalence of protection or compliance, but with application of a review function over the prior control by the Court of Justice over the exercise of any margin of appreciation. The ECHR's minimum floor of protection would operate as such, preventing action from swinging beyond the extreme on any one side of a conflict of rights (values) issue. There would end the role of the European Court of Human Rights in Strasbourg (ECtHR). Otherwise, it would be for the Court of Justice (or a Union Constitutional Court) to determine whether an EU law was or was not respectful of EU constitutional law in all its aspects including respect for common constitutional traditions and the essence of each Member State constitution.

2.13.3 No constitutional issues have been raised by the Maltese courts in a preliminary ruling request. However, as a matter of personal opinion following on from previous replies, the responsiveness of the CJEU will take the form of a revised role for the CJEU - or for a Union Constitutional Court if one were created. The Court would have a defined constitutional jurisdiction modelled on the very multi-level or horizontal (as I prefer) constitutionalism of the Union. Due deference would need to be paid to the essence of each national constitution, and to national identity as protected therein, while the principles of constitutional validity would be fully and better articulated and enforced at each 'level' (in each sphere). Comparative law techniques would serve as the basis for identifying and interpreting rights as part of the common constitutional traditions of the Member States. Similar rules would apply for establishing common values, which could also be articulated in the Treaty. Besides a strict review of EU measures, I would also favour dialogue about diversity, possible convergence through dialogue and then a degree of EU-level judicial review of national implementing measures for their observance or failure to observe the limits of the permitted exceptions to the exercise of Treaty rights and respect for recognised human rights and fundamental freedoms. The Treaty and the Charter oblige Member States to observe the Charter in implementing EU law. The EU Court must exercise full competence in this matter, including as to the limits on any margin of discretion permitted a Member State, while taking due account of such essential constitutional 'essence' as may be asserted.

2.13.4 In my view it would be legitimate to ask national institutions to be more pro-active in upholding the rule of law at Union level by ensuring a proper mesh with the national level. This could be done through proper implementation by the legislature or proper guidance by the national constitutional court, which could perhaps be given an advisory jurisdiction in such matters, ${ }^{62}$ without encroaching on

\footnotetext{
62 I envisage a kind of ex ante advisory constitutional jurisdiction, where the court indicates how in abstracto it would tend to view a certain issue from the constitutional perspective. This is different from the situation that exists in Malta, where the Constitutional Court has no advisory jurisdiction. It simply sees itself as having no competence to declare laws invalid, and it is of no effect if the ECtHR has declared them to be in breach of the Convention and therefore of the European Convention Act of Malta. This reduces the judgments of the ECtHR to mere 'advisory'
} 
parliamentary privileges such as the latter's role in monitoring the principle of subsidiarity and, I would add, proportionality, which is also properly seen as a constitutional principle. The national constitution should make as clear as possible what is within its essence (within the meaning of Art. 4(2) TEU) even if this means a new constitutional exercise at national level, possibly on the basis of a template to be prepared by the drafters of this Treaty provision. ${ }^{63}$ It is important that reference also be made to the other key constitutional value of the Union, namely solidarity, to emphasise the obligation to safeguard human and fundamental rights but above all the dignity of the person in all circumstances of Union action in each Member State. In this way the human dignity of the citizen will be placed first and foremost in the EU constitutional schema that consists both of the Treaty and national constitutions in the context of human and fundamental rights protection. True two-way loyalty, solidarity and goodwill in a properly synchronised constitutional space in the Union, offering respect for national identity and essential constitutional provision in each Member State, arguably require a fuller monitoring mechanism than only in relation to the principle of subsidiarity and only in virtue of a rather large number of objections. As far as respect for Art. 4 TEU is concerned, an ex ante objection procedure, and an ex post judicial review by the Court of Justice in dialogue with the national constitutional court, might be contemplated. The author believes that the opportunity should be taken as it arises to refine and develop Art. 4 (2) TEU, possibly by identifying the essential values constitutive of national identity (possibly on a 'compatibility with common traditions' test) and as highlighted in apposite national constitutional provisions.

\section{Constitutional Issues in Global Governance}

\subsection{Constitutional Rules on International Organisations and the Ratification of Treaties}

3.1.1 As to transfer of powers, reference has been made above to the 'EU amendment' made to Art. 65 of the Constitution on the exercise by Parliament of its legislative power. Not framed expressly as a transfer of power clause, but rather as an enabling and delimiting (limitation) clause that focuses on the exercise - by objective or purpose - of legislative power by the Parliament of Malta, the clause does not in express terms 'permit' but rather appears to 'recognise' the (therefore, presumably, inherent) capacity of the Maltese Parliament to transfer legislative

opinions, except in the case of the solution proposed here, where the judgment of the Constitutional Court would be applied.

63 Art. 4(2) TEU could be further developed from a synchrony, and mutual respect and loyalty, perspective. 
power pro tempore and pro tanto to the EU institutions or any international organisation or other entity by assuming international obligations which have that effect.

There is a general listing of particular objectives and of specific values and principles to be upheld when participating in international co-operation, such as might condition, and delimit the scope for, the exercise of this power. The power under Art. 65 must be exercised 'for the peace, order and good government of Malta' and 'in conformity with full respect for human rights, generally accepted principles of international law and Malta's international and regional obligations in particular those assumed by the treaty of accession to the European Union signed in Athens on the 16th April, 2003 [emphasis added]'. The words in italics indicate by reference that the objectives must be in conformity with the principles of international law and Malta's obligations under the Treaty of Accession to the EU. The provision therefore enshrines a loyalty obligation to the international rule of law and to the objectives and values that Malta shares as a member of the international community governed by international law and as a Member State of the European Union.

Additionally, Art. 1(3) of the Constitution declares that 'Malta is a neutral state actively pursuing peace, security and social progress among all nations by adhering to a policy of non-alignment and refusing to participate in any military alliance ...' (see further in Sect. 3.1.3).

By Art. 3(1) of the Ratification of Treaties Act, Act V of $1983,{ }^{64}$ where a treaty is one which affects or concerns (a) the status of Malta under international law or the maintenance or support of such status, or (b) the security of Malta, its sovereignty, independence, unity or territorial integrity, or (c) the relationship of Malta with any multinational organisation, agency, association or similar body, such treaty shall not enter into force with respect to Malta unless it has been ratified or its ratification has been authorised or approved in accordance with the provisions of the Act. The Act then provides in Art. 3(2) that in the case of (a) or (b) above, or where the treaty contains a provision which is to become, or be enforceable as, part of the laws of Malta, the ratification or the authorisation or approval of the ratification shall be by Act of Parliament. Article 3(3) expressly provides that no treaty shall become, or be enforceable as, part of the law of Malta except by or under an Act of Parliament. Here then, we have a strong form of dualism as far as concerns treaties falling within the scope of Art. 3(1). On the other hand, as to treaties that do not fall within the scope of Art. 3(1), Art. 5 provides that the Government's powers are not similarly constrained. Authorisation to ratify the Treaty of Accession of 16 April 2003 was given to the Government by Art. 6 of the European Union Act 2003.

There are no provisions in the Constitution specific to any international organisations or institutions other than the EU via reference to the Treaty of Accession of 2003.

${ }^{64}$ http://justiceservices.gov.mt/LOM.aspx?pageid=27\&mode=chrono\&gotoID=304. 
3.1.2 Article 65 was amended by Art. 7 of the European Union Act 2003 to include express reference to the ability of Parliament to legislate 'in conformity with' the obligations assumed by membership of the Union. ${ }^{65}$ It does not use the language of power to transfer or delegate powers. The wording appears to effect a 'clarification' of the 'breadth' of the Maltese Parliament's powers, which are assumed to include the power of transfer or delegation to organisations such as the EU. This would tally with the minimalist logic of a 'nation-oriented' or 'domestic-centred' constitution that sees and presents things from a domestic perspective (the powers of Parliament and their extent, rather than expressly conferring a transfer of power competence which would allow it to be said that a transfer had taken place) even if international obligations are undertaken that will at least pro tempore radically alter the legislative dynamic and bring into play a multilevel system of governance and constitutionalism. I believe this was partly a matter of constitutional culture, and perhaps partly a matter of deliberate political judgment as to what was acceptable to the people in 1993, as well as practicable (including acceptable to the opposition) in terms of constitutional amendment in order to 'accommodate' the idea of EU membership, as well as partly the fact that the future of Europe debate was still in train and academic rationalisations about European constitutionalism were in their youth, if not infancy. The language is the neutral language of stating that Parliament may legislate in order to transpose/transform a treaty (and obligations thereby assumed) into Maltese law - the classic dualist approach to international treaty law - without really addressing the fundamental constitutional issue of transfer of powers head on. In other words, the relative obligations are regarded as 'assumed' already by the treaty of accession, but made binding in Malta by virtue of the European Union Act passed in accordance with the parameters set out in Art. 65 . Again, it seems that all drafting was done by the Advocate General's office.

3.1.3 The courts, the Government or Parliament have not sought to re-open the question considered in the previous paragraph. On the other hand, it is different with regard to Malta's neutrality, which might be seen as an obstacle to full international co-operation whether at EU or even global level. Malta's neutrality was introduced, defined and enshrined in the Constitution in 1974, with amendment in 1987, in Art. 1(3) of the Constitution which reads:

Malta is a neutral state actively pursuing peace, security and social progress among all nations by adhering to a policy of non-alignment and refusing to participate in any military alliance. Such a status will, in particular, imply that: (a) no foreign military base will be permitted on Maltese territory; (b) no military facilities in Malta will be allowed to be used by any foreign forces except at the request of the Government of Malta, and only in the following cases: (i) in the exercise of the inherent right of self-defence in the event of any armed violation of the area over which the Republic of Malta has sovereignty, or in

65 Art. 65 of the Constitution reads: '65. (1) Subject to the provisions of this Constitution, Parliament may make laws for the peace, order and good government of Malta in conformity with full respect for human rights, generally accepted principles of international law and Malta's international and regional obligations in particular those assumed by the treaty of accession to the European Union signed in Athens on the 16th April, 2003.' 
pursuance of measures or actions decided by the Security Council of the United Nations; or (ii) whenever there exists a threat to the sovereignty, independence, neutrality, unity or territorial integrity of the Republic of Malta; (c) except as aforesaid, no other facilities in Malta will be allowed to be used in such manner or extent as will amount to the presence in Malta of a concentration of foreign forces; (d) except as aforesaid, no foreign military personnel will be allowed on Maltese territory, other than military personnel performing, or assisting in the performance of, civil works or activities, and other than a reasonable number of military technical personnel assisting in the defence of the Republic of Malta; (e) the shipyards of the Republic of Malta will be used for civil commercial purposes, but may also be used, within reasonable limits of time and quantity, for the repair of military vessels which have been put in a state of non-combat or for the construction of vessels; and in accordance with the principles of non-alignment the said shipyards will be denied to the military vessels of the two superpowers [emphasis added].

As I have written elsewhere, ${ }^{66}$ it is arguable that the second clause of paragraph (e), in particular, may be regarded as redundant in light of the ending of the Cold War (at least the first one, for we may be on the threshold of the second). It has also been argued that the entire provision centres around a policy of 'non-alignment' (as between 'the superpowers' - which may now be more than the 'old' two, at least in prospect), rather than strict neutrality, and that non-alignment is not a fixed concept in international law but must bear reference also to the climate of the time when the provision was adopted. This type of reasoning calls much into question, also in light of the evolution of the role and competence of the Union in the sphere of Foreign and Security Policy. One recalls the duty of loyalty under the Treaty but also the objectives of the Union especially post-Lisbon. Indeed, the provision speaks of an 'active' neutrality, one that is intended to actually permit Malta to be pro-active in the pursuit of peace, security and social progress among all nations. This does not indicate a passive stance. While participation in a military alliance is excluded (Malta was told in the course of membership negotiations that the EU was not such and was not to become such), the ban on the use of Maltese facilities by foreign military forces is open to a number of exceptions, one of which is the pursuance of measures or actions decided by the Security Council of the United Nations. This all shows that the matter is not clear cut, and that some think that an attempt at 'clarification' of Malta's international active neutrality status should be made in any constitutional review exercise that may be undertaken if this status is to be generally understandable within the context of our membership of the EU and within the new global context. Therefore, the neutrality clause is one clause that has been identified as being in need of review/revision in light of developments relating to Malta's EU role and to changes on the international scene.

3.1.4 The declared constitutional commitment of Malta to the social progress of all peoples will be commented upon in response to question 3.5. Suffice to point out

\footnotetext{
66 See Xuereb 2001, 2006. See also EC Directorate, Ministry of Foreign Affairs, Department of Information Report, 1990, pp. 153-154.
} 
here that Art. 1(3) commits Malta to actively pursue some global desiderata. Malta's neutrality was seen as a means to that end. The commitment is to actively use our status as a non-aligned independent state with a wide range of commercial, cultural and philosophical ties as well as proximity to the two main sides of the Mediterranean putting us on the frontier with the Arab world and Africa, and placing us at the centre of all Mediterranean states, and to do so for peace, prosperity and justice. Malta's foreign policy has rested on these pillars ever since. It might be termed Malta's international vocation, as enshrined in its Constitution. Any revision of the Constitution can be expected to build upon the perceived international vocation of Malta going forward into the future. I therefore certainly do not exclude the possibility of developing this clause into one mandating a more general pro-active and active approach to upholding democracy, the rule of law and human rights in the context of global governance, while placing this also in the context of EU membership.

\subsection{The Position of International Law in National Law}

3.2.1-3.2.2 As emerges clearly from Art. 65 of the Constitution, and Art. 3 of the Ratification of Treaties Act of 1983 as amended, Malta is in principle a dualist state. Although there has been no real debate on this in Malta, Malta is aware of the fact that some other Member States adopt a monist stance - at least when it comes to membership of the EU, but often as a general stance. There have been no arguments in favour of abandoning the dualist stance, although again Malta is aware that the European Union Act 2003 has the effect of making 'directly applicable' EU law directly applicable in Malta, and that this is not a strict dualist position, but then it is recognised that EU law is not ordinary international law. In short, in my view constitutional constructs and doctrines apply as modified and transformed in the EU membership context. We need to be constantly aware of the sui generis nature of the EU and its legal order. It is this new order that can then help explain, inform and give language to the new constitutionalism in Malta itself and at the same time to the regional and world orders now evolving.

\subsection{Democratic Control}

3.3.1 There have been occasional calls for a greater role ex ante in foreign affairs for the Maltese Parliament. For example, it was a cause of some chagrin when a commitment was given in relation to Partnership for Peace involvement (re-activation) without any reference, far less discussion, in the House, leading to 
the resignation of the head of the Maltese representation in Brussels. ${ }^{67}$ Another example is the granting of permission for warships to use Maltese shipyards.

In terms of thinking about Parliament's involvement at the stage of implementing international commitments, a useful starting point is the case of the EU, with two key examples being the need to transpose directives and the ex ante scrutiny or ex post challenge of Commission proposals/adopted legislation for compliance with the principle of subsidiarity. A key development, in the author's view, would be the ex ante scrutiny of a European Commission proposal or any Union act for compliance with human rights in accordance with the national constitution. Issues have arisen in Malta in relation to the principle of proportionality, where Malta took the position that a proposal went against the principle but had to accept the Commission's stance that the procedure of ex ante control does not extend to this principle, despite the wording of the title of Protocol No 2. The Latvian example on the IMF conditionality given in the questionnaire shows that other issues can arise, in the broader context of global governance, in relation to other general principles of law, which should be recognised as having constitutional status.

3.3.2 The Constitution neither expressly permits nor prohibits the holding of referendums on international organisations or international treaties. This does not mean that a referendum may not be held, but simply that it has no constitutionally binding effect, so that any result is binding only in political terms. Such was the referendum of 2003 on the question whether Malta should join the European Union.

\subsection{Judicial Review}

3.4.1 There is no mechanism in Maltese law for the review of Treaties and measures adopted under international law, separate from the challenge of the Maltese implementing decisions or laws under the Constitution. In this connection, the institution of a mechanism at EU level for the challenge of a prospective EU measure for breach of some general principle of law would allay the need for an individual Member State to raise the issue of validity of EU law under constitutional law ex post, for it would raise the issue as a 'constitutional' issue under EU law of the validity of the measure of another international organisation directly within the EU. There should, however, be some mechanism which would permit a Member State to participate in the Union review process. Similar thinking ought to take place in the context of global governance.

67 Vella, M. (2012, April 20) Update 2 Government reacts to Labour motion for Richard Cachia Caruana's resignation. Malta Today. http://www.maltatoday.com.mt/news/national/17598/labourmotion-calls-for-resignation-of-richard-cachia-caruana-20120420\#. 


\subsection{The Social Welfare Dimension of the Constitution}

3.5.1 The debate as to 'social Europe' at the time of the referendums on the Treaty establishing a Constitution for Europe (the so-called and ill-fated 'Constitutional Treaty') was closely followed in Malta. The social dimension of the Treaties is an important one in Malta's eyes. The accountability of the institutions, and of all decision-makers, including in the economic sphere, and of the new 'European' regulators, is a matter of real interest, which many in Malta trust will continue to be addressed at all levels and especially throughout the sphere of economic and financial governance. It would be well for the principles and liabilities to be expressly spelt out and for appropriate investigative mechanisms to be put in place, thus mirroring political accountability under the national constitutions. There is every reason to extend this, possibly by EU initiative, to non-EU, global financial and economic institutions.

3.5.2 Malta has not been subject to a bailout and austerity programme. It has watched with concern as others have defaulted or been rescued, and it has been with a degree of chagrin that Malta has had to accept the imposition of central solutions against the wishes and to the sacrifice of whole populations while proper accountability and punishment appear to have been lacking both in the public and in the private spheres in those Member States in which the worst defaults were committed. Nor have Member States been able to agree easily on the solutions, demonstrating that solidarity could be better organised and underpinned by the European constitutional level.

\subsection{Constitutional Rights and Values in Selected Areas of Global Governance}

3.6.1 Regarding the proposition about the erosion of constitutional rights, the rule of law, judicial review, democratic control, or accountability in the face of global threats or pressures, Malta has not remained entirely untouched but has, in general, not had to adopt draconian anti-terrorist legislation and so on of its own beyond what has been adopted at European Union or other wider international level.

\section{References}

Aditus et al. (2014) NGO Submissions to the Ministry for Social Dialogue, Consumer Affairs and Civil Liberties (Human Rights \& Equality Consultation) March 2014. http://aditus.org.mt/ Publications/scopinginput_032014.zip.

Azzopardi A. (2012) Malta. In: Laffranque J. (ed.) The Protection of Fundamental Rights Post-Lisbon, Reports of the XXV FIDE Congress Tallinn 2012, Vol. 1, Tartu University Press, Tallinn, pp. 627-640. 
Central Bank of Malta (2013) The Evolution of Economic Governance in the European Monetary Union. http://www.google.com.mt/url? $\mathrm{sa}=\mathrm{t} \& \mathrm{rct}=\mathrm{j} \& \mathrm{q}=\& \mathrm{esrc}=\mathrm{s} \&$ source=web\&cd=5\&cad=rja\&uact= $8 \& v e d=0 \mathrm{CDYQFjAE} \& u r l=\mathrm{http} \% 3 \mathrm{~A} \% 2 \mathrm{~F} \% 2 \mathrm{Fwww}$. centralbankmalta.org\%2Fupdates\%2Fdownload s\%2Fpdfs\%2FEconomic_governance_reform.pdf\&ei=yEYQVLnFG8iR7AaCroHACg\&usg=AFQj CNF5W4tDMhfRKKI8EA3QJCZBJqodGw\&bvm=bv.74649129,d.ZGU.

Constitutional Court of the Republic of Malta. Report. The relations between the Constitutional Courts and the other national courts, including the interference in this area of the action of the European courts. XII Congress of the Conference of European Constitutional Courts, Brussels, 13-17 May 2002. http://www.confeuconstco.org/reports/rep-xii/Malta-EN.pdf.

Cremona J.J. (1997) The Maltese Constitution and Constitutional History since 1813, 2nd Edition. Publishers Enterprises Group (PEG) Ltd., San Gwann.

Degaetano V. (2008) Report for Malta. Problems of Legislative Omission in Constitutional Jurisprudence. Questionnaire for the XIV Congress of the Conference of European Constitutional Courts, 2-7 June 2008, Vilnius. http://www.judiciarymalta.gov.mt/home?l=1.

Dyer C. (2000) Conjoined twins separated after long legal battle. BMJ 321(7270):1175 et seq.

European University Institute (2013) Constitutional Change through Euro Crisis Law: Country Reports on the impact of crisis Instruments on the legal structures of the EU Member States. Malta. http://eurocrisislaw.eui.eu/country/malta/topic/fiscal-compact/.

Filletti S. (Undated) Replies to Questionnaire regarding the European Arrest Warrant and its implementation in the Member States of the EU. In the European Arrest Warrant database. http://www.law.uj.edu.pl/ kpk/eaw/data/malta.html.

Mifsud Bonnici G. (2004) Constitutional Procedure Relative to Fundamental Rights and Freedoms. Midsea books, St. Venera.

Office of Official Publications of the European Union (2014) Malta u 1-Qorti tal-Gustizzja Tal-Unjoni Ewropea (Malta and the Court of Justice of the European Union). Curia, Luxembourg.

Sammut I. (2009) The EU and Maltese Legal Orders: What Kind of Marriage Between Them? In: Xuereb P.G. (ed.) Malta in the European Union: Five Years On and Looking to the Future. Malta, European Documentation and Research Centre, University of Malta, pp. 97-112.

Sammut I. (2012) Malta. In: Laffranque J. (ed.) The Area of Freedom Security and Justice, Including Information Society Issues, Reports of the XXV FIDE Congress Tallinn 2012, Vol. 3. Tartu University Press, Tallinn, pp. 461-482.

The Today Public Policy Institute (TPPI) (2014) A Review of the Constitution of Malta at Fifty: Rectification or Redesign? http://www.tppi.org.mt/ user2/index.php/reports.

Weiler J.H.H. (1999) The Constitution of Europe. Cambridge University Press, Cambridge.

Xuereb P.G. (2001) Constitutional Questions Raised by the Proposed Accession of Malta to the European Union in the General Context. In: Kellermann A. de Zwaan J.W., Czucza J. (eds.) EU Enlargement: The Constitutional Impact at EU and National Level. TMC Asser Press, The Hague, pp. 229-242.

Xuereb P.G. (2002) The Future of Europe: Solidarity and Constitutionalism. Towards a Solidarity Model. E.L.Rev. 6:643-662.

Xuereb P.G. (2006) Malta. In: Kellermann A., Czuczai J., Blockmans S., Albi A., Douma W.T. (eds.) (2006) The Impact of EU Accession on the Legal Orders of the New Member States and (Pre-) Candidate Countries. TMC Asser Press, The Hague, pp. 409-419.

Xuereb P.G. (2012) A Common Goods' Understanding of Europe and the World. In: Bekemans L. (ed.) A Value-Driven European Future. Peter Lang, Brussels, pp. 159-180.

Zammit D.E. (ed.) (2008) Maltese Perspectives on Human Rights. Malta University Press, Malta. 
Open Access This chapter is licensed under the terms of the Creative Commons Attribution 4.0 International License (http://creativecommons.org/licenses/by/4.0/), which permits use, sharing, adaptation, distribution and reproduction in any medium or format, as long as you give appropriate credit to the original author(s) and the source, provide a link to the Creative Commons license and indicate if changes were made.

The images or other third party material in this chapter are included in the chapter's Creative Commons license, unless indicated otherwise in a credit line to the material. If material is not included in the chapter's Creative Commons license and your intended use is not permitted by statutory regulation or exceeds the permitted use, you will need to obtain permission directly from the copyright holder.

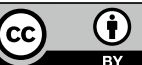

